\title{
АНАЛИЗ СИНХРОННЫХ РЕЖИМОВ РАБОТЫ ЦЕПОЧКИ СВЯЗАННЫХ ОСЦИЛЛЯТОРОВ ЭНЕРГОСЕТЕЙ
}

\author{
П. А. Аринушкин, В. С. Анищенко
}

Саратовский национальный исследовательский государственный университет

Россия, 410012 Саратов, ул. Астраханская, 83

E-mail: arinushkin.pavel@gmail.com,wadim@info.sgu.ru Поступила в редакиию 12.03.2018

Цель исследования - формулировка эффективной модели энергосети, определение устойчивых режимов ее работы, выявление различий рассматриваемых режимов и проведение тестов на устойчивость системы к изменениям управляющих параметров, начальных условий и к различным типам внешнего воздействия. Метод. Рассматривается введенная авторами эффективная модель энергосети, состоящая из трех связанных осцилляторов, при различных способах задания начальных условий и вариации управляющих параметров. Численное моделирование энергосистем позволяет выявить устойчивые состояния осцилляторов, при которых наблюдается стабильная работа энергосистем. Данный подход дает возможность произвести оптимизацию энергосистем, определить механизмы повышения стабильности системы и выявить участки энергосистем, которые более подвержены негативным факторам. В рамках исследования было проведено сравнение режимов работы энергосети в условиях воздействий внешнего шума различной интенсивности и прямоугольных импульсов, которые моделируют скачки мощности в энергосети. Результаты. Предложена и численно исследована эффективная модель энергосистемы, состоящая из трех связанных генераторов. Показано, что при изменении выходной мощности генератора можно получить режим, устойчивый к вариациям начальных условий. Установлено, что функционирование такой системы оказывается менее чувствительным к различным внешним факторам. В частности, режим с синхронизацией фазовых скоростей всех осцилляторов является более устойчивым к перепадам потребляемой мощности, шумовым эффектам и к разрывам линий передач в сравнении с режимом синхронизации с различающимися фазовыми скоростями. Обсуждение. Исследование энергосети трех связанных генераторов продемонстрировало поведение ключевых режимов работы энергосетей и показало возможность оптимизации сети посредством регулировки параметра выходной мощности генератора. В данной работе рассмотрена синхронизация энергосетей всего лишь для одной модели сети. В качестве дальнейшего изучения сетей необходимо провести сравнительный анализ режимов синхронизации нескольких моделей энергосетей.

Ключевые слова: энергосети, синхронные машины, фазовые осцилляторы, синхронизация связанных генераторов, устойчивость динамического режима.

DOI: $10.18500 / 0869-6632-2018-26-3-62-77$

Образеи ичитирования: Аринушкин П.А., Анищенко В.С. Анализ синхронных режимов работы цепочки связанных осцилляторов энергосетей // Известия вузов. Прикладная нелинейная динамика. 2018. Т. 26, № 3. С. 62-77. DOI: 10.18500/0869-6632-2018-26-3- 62-77 


\title{
ANALYSIS OF SYNCHRONOUS MODES OF COUPLED OSCILLATORS IN POWER GRIDS
}

\author{
P. A. Arinushkin, V. S. Anishchenko \\ Saratov State University 83, Astrakhanskaya, 410012 Saratov, Russia \\ E-mail: arinushkin.pavel@gmail.com,wadim@info.sgu.ru \\ Received 12.03.2018
}

\begin{abstract}
Aim. The aim of the study is to formulate an effective model of the power grid, to determine the stable modes of its operation, to identify differences in the considered modes and to test the stability of the system to changes in control parameters, initial conditions and to various types of external influence. Method. The effective model of the energy network, which consists of three coupled oscillators, is considered for different methods of setting the initial conditions and variation of the control parameters. Numerical simulation of power systems allows to reveal the steady states of the oscillators, at which the stable operation of power systems is observed. This approach makes it possible to optimize power systems, to determine the mechanisms for improving the stability of the system and to identify the parts of power systems, that are more prone to negative factors. In the framework of our study, the operating modes of the power grid are compared under the influence of external noise of different intensities and rectangular pulses, which simulate power surges in the power grid. Results. The effective model of the power system consisting of three coupled generators has been proposed and numerically explored. It is shown that when the output power of the generator is changed, a regime which is resistant to variations of the initial conditions can be obtained. It is found that the functioning of such a system is less sensitive to various external factors. In particular, the mode with synchronization of phase velocities of all the oscillators is more resistant to power consumption changes, noise effects and transmission line breaks in comparison with the mode of synchronization with different phase velocities. Discussion. The study of the power grid of three coupled generators has demonstrated the behavior of the key modes of operation of the power grids and has shown the possibility for optimizing the network by adjusting the generator output power parameter. In this paper, we have considered the synchronization of power grid for only one model of the network. As a further study of networks, it is necessary to conduct a comparative analysis of synchronization modes of several power grid models.
\end{abstract}

Key words: power grids, synchronous machines, phase oscillators, synchronization of coupled generators, stability of dynamic modes.

DOI: $10.18500 / 0869-6632-2018-26-3-62-77$

Reference: Arinushkin P.A., Anishchenko V.S. Analysis of synchronous modes of coupled oscillators in power grids. Izvestiya VUZ, Applied Nonlinear Dynamics, 2018, vol. 26, no. 3, pp. 62-77. DOI: 10.18500/0869-6632-2018-26-3-62-77 